\title{
Collaborative, Capacity Development Efforts: A case of Kampung Hujung Rintis, Perak and UiTM Cawangan Selangor, Malaysia
}

\author{
Rugayah Hashim¹, Zaidi Mohd Aminuddin², Ayu Rohaidah Ghazali², Norfadzilah Abd Razak² \\ 1 Research \& Innovation Unit, 2 Faculty of Business \& Management, \\ Universiti Teknologi MARA Cawangan Selangor, Puncak Alam, Selangor, Malaysia \\ guy73106@yahoo.com, pmzaidi@yahoo.com.my, ayurohaidah@gmail.com, norfadzilah0438@gmail.com \\ Tel: +6013-3852288
}

\begin{abstract}
Public universities have been directed to have more collaborative projects with disadvantaged communities for capacity and sustainable developments. In the case of Universiti Teknologi MARA, Selangor Branch (UCS), the success stories on community engagement and capacity development have been shown with Kampung Hujung Rintis, Perak, Malaysia. This paper aims to showcase impacts on collaborative efforts through a live research laboratory for data collection using multiple techniques. The feedbacks from crossdisciplinary projects were for the implementation of capacity-development initiatives at Kampung Hujung Rintis. The implications from the case events showed that continuous community engagements would be beneficial for all parties involved.
\end{abstract}

Keywords: Capacity Development; Disadvantage Communities; Research Co-production; Sustainable Development

eISSN: 2398-4287 (C) 2019. The Authors. Published for AMER ABRA cE-Bs by e-International Publishing House, Ltd., UK. This is an open access article under the CC BYNC-ND license (http://creativecommons.org/licenses/by-nc-nd/4.0). Peer-review under responsibility of AMER (Association of Malaysian Environment-Behaviour Researchers), ABRA (Association of Behavioural Researchers on Asians) and cE-Bs (Centre for Environment-Behaviour Studies), Faculty of Architecture, Planning \& Surveying, Universiti Teknologi MARA, Malaysia.

DOI: https://doi.org/10.21834/e-bpj.v4i12.1751

\subsection{Introduction}

Public universities' researchers have been conducting fundamental studies as befitting the need for new knowledge expansion. However, the time has come for research outcomes to impact the people and the industry. Also, many research funding and grants have been awarded to researchers with findings and results that were, inherently, converted into conference oral presentations, proceedings, or journal articles. The impact of post-harvest research and development from the studies would make a valuable contribution to the poor, rural communities, as pointed out by Huyse, Molenaers, Phlix, Bossuyt, and Fonteneau (2012). For this investigation, the underpinnings on research co-production formed the basic approach to the project. Also, the inductive approach to achieving the projects' objectives was the motivation for the activity.

In capacity development, the communities play important roles together with the support of the local government (Möller, 2020). Before moving on, it is best to understand the difference between capacity building and capacity development. As clearly noted by Zamfir (2017), "capacity-building suggests building something new from the ground up" based on pre-imposed design. On the other hand, capacity development is "an approach that builds on existing skills and knowledge, driving a dynamic and flexible process of change, borne by local actors" (ibid). Definitions aside, the use of capacity development fits this paper. Nevertheless, the ultimate goal is the collaboration is social inclusion, socio-economic growth, sustainable development, and well-being for the rural citizens. This paper is, in fact, a narrative of the case study. The scope of the case is Kampung Hujung Rintis, in the state of Perak, Malaysia. The choice of the location originated from the invitation by a post-graduate student who hails from this rural area. In the interest of socio-economic growth, the research team from the university congregated with multiple discussions and visits to the location to ensure the viability of

eISSN: 2398-4287 @ 2019. The Authors. Published for AMER ABRA cE-Bs by e-International Publishing House, Ltd., UK. This is an open access article under the CC BYNC-ND license (http://creativecommons.org/licenses/by-nc-nd/4.0/). Peer-review under responsibility of AMER (Association of Malaysian Environment-Behaviour Researchers), ABRA (Association of Behavioural Researchers on Asians) and cE-Bs (Centre for Environment-Behaviour Studies), Faculty of Architecture, Planning \& Surveying, Universiti Teknologi MARA, Malaysia. DOI: https://doi.org/10.21834/e-bpj.v4i12.1751 
the project. Given the objectives and project design, the various scopes for numerous studies available for researchers through the live laboratory case studies were undertaken at two university-based community engagement events. Demographic profiles of the villagers at Kampung Hujung Rintis were provided by the village chief (Penghulu). These were used to analyze socio-economic patterns. In fulfilling UCS's vision of "Research Benefiting People and Industry," the joint programs between UCS and Kampung Hujung Rintis were achieved through two events in September 2018 and April 2019. The elaboration on the scope will be narrated in the methodology section.

\subsection{Literature Review}

Higher learning institutions or universities play essential roles in a country's socio-economic growth. Besides the contemporary tertiary education curriculum for the next set of qualified workers, universities are advocated to engage with various communities for knowledge sharing and other relevant exchanges. The potential roles of academic and research institutions in capacity building and sustainable development, especially in disadvantaged areas, are impact-oriented (Bodorkos \& Pataki, 2009). Universities, too have corporate social responsibilities. To fulfill these responsibilities, the apt method is through research co-production (ibid) and, the scope chosen should be a socio-economically disadvantaged local area. Evidence of a successful collaborative, co-production activity between a community in a rural area with a university expert was in Nakuru County, Kenya (Restrepo, Lelea, \& Kaufmann, 2018), where knowledge integration resulted in the successful learning process with smallholder dairy farmers. Collaborative activities offer stakeholders interactions leading towards sustainable development (Schneider \& Buser, 2018).

Food security has become a priority agenda for all countries. With climate changes and global warming, some societies are deprived of food. Working on the food security imperatives, this project observed the necessity for villagers in Kampung Hujung Rintis to take advantage of their natural flora and fauna environment for sustainable development. Doing so involved ecosystem services research, as advocated by Cruz-Garcia, Sachet, Vanegas, and Piispanen (2016). Capacity building is vital in ensuring food sustenance for communities in rural areas.

For collaborative capacity efforts, another alternative is community-based tourism (Kline, McGehee, \& Delconte, 2019). This agenda utilizes the rural, indigenous ambiance as the attraction for tourism activities. Through collective community-based tourism projects, the stakeholders will benefit as each project will create new social and human capital as well as improving the community's psyche, foster confidence, belongingness, and wellbeing (ibid). Communities coming together as one will foster cohesion, social inclusion, and happiness. With Kampung Hujung Rintis, the opportunities for eco-tourism have been mooted several times by the village cooperative, the local councilors, and the village chief. Undertaking eco-tourism requires extensive community involvement as cautioned by Abu Bakar and Wall (2018). That said, offshoots from tourism will result in entrepreneurial opportunities for small-holders and other homebased, traditional products that are associated with that area.

Most collaborative efforts between a university with a community are for closing the gaps with win-win objectives. An example of that objective is education for sustainable development (Nuamcharoen \& Dhirathiti, 2018). Thailand, for instance, besides promoting education for rural folks, the collaboration activity for both parties allows for the learning of cultural and traditional events, information technology and media usage, other contingency approaches, which will lead towards an equitable, sustainable future (ibid). Another advantage to the university in undertaking collaborative efforts for the university to the community is corporate social responsibility (CSR) (Ahmad, 2012). It is observed that CSR elements underpin these events too.

Additionally, there are ethical principles when undertaking a community-based collaborative project. First of all, there has to be mutual respect in developing research relationships (NCCPE, 2012). The commitments include agreeing to what counts as mutual respect in particular contexts, that everyone involved should be prepared to listen to the voices of others and, accepting that people have diverse perspectives, different forms of expertise and ways of knowing that may be valuable in the research process (ibid). For the two events, there was conformation to the ethical practices. Also, there is equality and inclusion matter, such as encouraging and enabling people for a range of backgrounds and identities (for example, ethnicity, class, education, gender, disability, age, etc.) to lead, design, and take part in the research (ibid). Another essential element when dealing with community engagement efforts is synchronous active learning for both the university representatives and the villagers. Research collaboration and the process of research need to be seen as providing opportunities for learning from each other. After the events, there have to be reflection reports or, in our case, the post-mortem meeting to identify the advantages and disadvantages of the two events. In other words, the beneficial outcomes and the shortcomings that can be rectified should there be another similar activity.

The literature reviewed has shown that community development efforts that are collaborated with universities do bring exponential benefits, particularly for cottage industries. The research projects available from the live laboratories are infinite. The co-production research method, as sanctioned by Banks, Hart, Pahl, and Ward (2019), will evoke experiential knowledge for the communities and vice versa. The theories learned can be applied to relevant cases through research co-production. This will then enable new knowledge creation that can lead to positive changes to the communities, especially those in the rural areas. In terms of research cluster, opportunities for various studies for those in the humanities and social sciences are available. In having a real, live scope for research investigations, the impact on the communities themselves can be realized, specifically for the socio-economic agenda of the state of Perak and for the federal government of Malaysia. For the universities' research projects that require product commercialization, these collaborative efforts will allow for significant networking. In fact, for the universities, the agreements on the consultancy projects were through the memorandum of understanding (MOU).

Most importantly, the collaborative efforts benefit the students by giving them real, live platforms in terms of place and people. The diversity of scopes for researchers from various fields of medicine, genomics, etc. are readily available through these kinds of events. 
From the research standpoint, short-term research projects can focus on easily measurable outcomes, but real partnerships can emerge from the connections with the communities. These are the same views as Banks et al. (2019). Therefore, universities in Malaysia should continue to engage in collaborative efforts for capacity development success. To quote Howard Zinn, an American historian and social activist (in Banks et al., 2019):

If we do act, in however small a way, we do not have to wait for some grand utopian future. The future is an infinite succession of presents. Moreover, to live now as we think human beings should live, in defiance of all that is bad around us, is itself a marvelous victory.

\subsection{About Kampung (Kg.) Hujung Rintis, Mukim Kota Setia, Perak}

Kampung (short form, Kg.) Hujung Rintis is a segment of a larger group of villages under the central umbrella of $\mathrm{Kg}$. Sungai Besar, Mukim Kota Setia, Teluk Intan, Perak (Fig. 1).

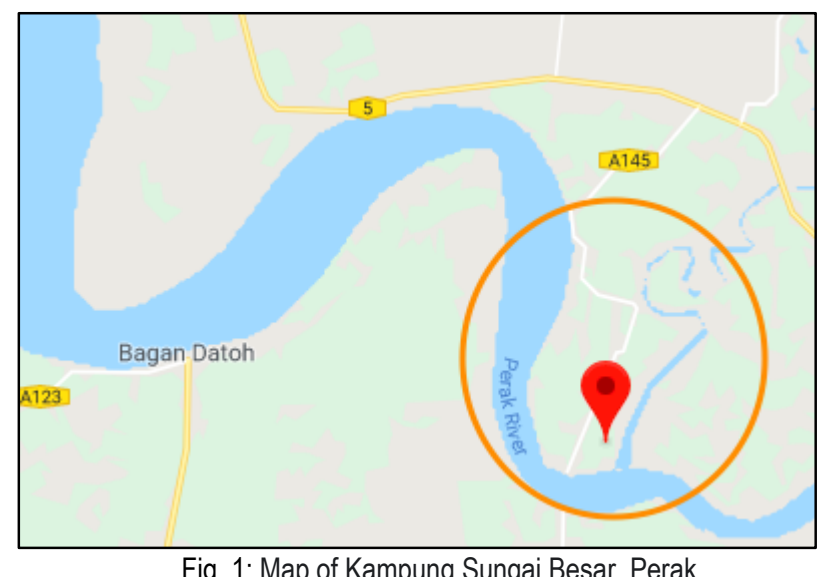

Fig. 1: Map of Kampung Sungai Besar, Perak

(Source: Google Map, 2019)

The rest of the villages are Kg. Sungai Nibung, Kg. Sungai Mengkudu, Kg. Tengah, Kg. Sungai Bahan, Kg. Kandang (formerly, Kg. Kandang Kerbau), Kg. Teluk Ketapang dan Kg.Tebuk Haji Kori (Rintis, 2019). Kg. Hujung Rintis is also known as Desa Muara Hujung Rintis, as it is located at the end of the peninsula (Fig. 1). Because of its isolated location, $\mathrm{Kg}$. Hujung Rintis has not been spoiled by over-development. The lifestyle for the villagers here is slow-paced. There are tourist attractions at Desa Muara Hujung Rintis, for example, firefly watching, boat rides on the Perak River, observing wildlife and migratory birds, fishing for freshwater prawns (udang galah in Bahasa Melayu) and others.

\subsection{Methodology}

Research co-production was the approach used for the community-university collaboration, as advocated by Banks et al. (2019). In explaining the capacity building to the co-production of research, this means that studies were collaboratively undertaken by "several parties that values multiple perspectives and voices; contributes to creating and developing communities of place, interest, and identity; builds collective capacity for action, and works towards social change" (ibid). Also, elements of cross-disciplinary and translational practices were incorporated into the research living laboratory events. For both approaches, the application of the researchers' expertise during both events was translated into direct benefits to the communities. Two events (September 2018 and April 2019) allowed for the successful capture of data from attendees through surveys, repeated observations, informal conversations, and other forms of inquiries. The presence of researchers from multiple disciplines based at Universiti Teknologi MARA, Cawangan Selangor (UCS), allowed for critical projects to complete data collection. The faculty members involved in this live laboratory research events were from the Faculty of Business and Management, the Faculty of Accountancy, the Faculty of Information Management, the Faculty of Hotel and Tourism Management, the Faculty of Health Sciences, the Faculty of Dentistry and, the Faculty of Education. The administrative departments involved in these two events were from the Tun Abdul Razak Library (PTAR), the Campus Police Department, the Counseling Division and, the Research and Innovation Division. As for the unit of analyses, these consisted of a combined 530 (Table 1) villagers from Kg. Hujung Rintis, Mukim Kota Setia, Perak for the two events.

Table 1. Attendees for Hujung Rintis (HR) 1.0 and 2.0

\begin{tabular}{|c|c|c|}
\hline Event & September 2018 & April 2019 \\
\hline HR 1.0 & 267 & - \\
\hline HR 2.0 & - & 263 \\
\hline
\end{tabular}




\subsection{Outcomes and Implications of Projects}

\subsection{Project Outcomes and Implications for the University}

There were multiple outcomes from the two collaborative, capacity building efforts by Universiti Teknologi MARA, Cawangan Selangor (UCS):

Firstly, demographic profiling of the villagers; these data will assist the social science researchers from the university and relevant stakeholders' for capacity development. UCS's mobile eye and dental clinics (buses) facilitated the activities through free checkups for the villagers.

Secondly, the utilization of university resources for community development, particularly from the research scope standpoint. The researchers were able to gather immediate, rich data for analyses.

Thirdly, approvals for evaluating the various built environment available at $\mathrm{Kg}$. Hujung Rintis and the nearby infrastructure such as jetties, roads, etcetera for correlation to sustainable development.

Fourthly, other historical, cultural, and traditional elements indigenous to the state of Perak were noticeably observed and annotated for future research endeavors in the fields of arts and humanities.

Fifth, the full range of translational and transdisciplinary research projects' opportunities through the inductive approach for the various faculties or schools at UCS. The collaborative initiatives allowed for a more effective and principled research co-production.

Sixth, continued engagement will blur the lines of impartiality between the university and the communities.

Seven, collaborative efforts make the university more visible to the public while sharing resources and building networks.

Eight, collaborative community projects will ensure social inclusion and more connected society.

Nine, villagers involved in small, cottage industries and local entrepreneurship projects were given short, workshop training such as basic accounting, records management, product marketing, speed reading for the students, academic mission briefings, new culinary dishes from indigenous plants and game, etcetera.

Ten, consultation projects through business matching and pitching. The guests were from micro-financing companies.

Eleven, opportunities for university students to engage with the villagers through face-to-face interactions that fulfill the university's Academic Affairs agenda on "Week without Walls" and "Wisdom Wednesday."

Twelve, the opportunities for further collaborative, institutional studies with other local universities that would fulfill the criteria for specific research grants awarded by the various federal ministries and other agencies in Malaysia.

Lastly, opportunities for student entrepreneurship and internships. The Ministry of Education and the local public universities have advocated the need for students to go into entrepreneurship. Having hands-on and face-to-face discussions with community leaders and state leaders would provide many opportunities to do so. Networking with the grassroots would also offer rich insights for a two-way product marketing and promotion. Besides the students, the university administrative staff involved with the community development projects stand a chance to network and be part of the business joint ventures, partnerships, and entrepreneurship.

\subsection{Project Outcomes and Implications for the Community}

For the community, as analyzed and compiled from the feedbacks by the villagers, the communal leaders, and district head, the outcomes and implications were:

First, the bonding between the kampong folks (villagers) and the university representatives (the UCS Rector, students, and staff). The inductive approach used in this research co-production activities bore fruit in more ways than were anticipated. The projects evoked social cohesion, warmth, inclusivity, care, and a sense of communality.

Second, for the villagers involved in cottage entrepreneurship, micro-financing assistance was extended by banks and other relevant government agencies. These transactions were possible after the first workshops on accounting literacy and records management. Once the cottage entrepreneurs have put their documents into a systematic order, the success of four entrepreneurs from $\mathrm{Kg}$. Hujung Rintis in getting micro-financing assistance were observed.

Third, the free eye-checks given to the villagers resulted in sponsorship for spectacles or eyeglasses. Students from the Department of Optometry, Faculty of Health Sciences were given real-life cases to practice, guided by their lecturers. However, priority was given to 30 senior citizens. The implications from the positive outcomes were trust and affinity towards Universiti Teknologi MARA as before the first event; most village folks were apprehensive about the university's community engagement efforts as the event was a first for Kg. Hujung Rintis. This means that there should be follow-ups by the university researchers involved in the activities and not let the event be a one-off agenda.

Fourth, another free service was by UiTM's Faculty of Dentistry's mobile dental bus. Again, dental students and lecturers were afforded real-life cases to practice and annotate for comparative studies. The outcome from this is another sponsorship by the Faculty of Dentistry in the form of free dentures to 30 senior citizens at Kg. Hujung Rintis. Similar implications were observed for this event as the free eyecheckups.

Fifth, the two events swiftly became the talk of the town through word-of-mouth exchanges. There have been requests by other village heads located in other Perak districts to host similar events. These requests are evidence of confirmation to UiTM's noble community engagement services.

Six, ever since the first event, there have been notable infrastructure developments leading to Kg. Hujung Rintis. For instance, new electrical pillars were installed, the inner and the backyard roads and lanes were resurfaced. 
Lastly, the two community service follow-ups for free eyeglasses (spectacles) and dentures for the senior citizens from B40 (bottom 40\% group (of the median income level below MYR3,000) showed that the university's data on income disparity among the disadvantaged group is confirmed. In other words, $100 \%$ of $\mathrm{Kg}$. Hujung Rintis's population is placed in the B40 category. This means that the community has a weak economic ability.

\subsection{Limitations, Challenges and Recommendations}

The limitations to the live research project were:

- the sample size; the limited number of villagers who turned up for the survey was less than five percent of the population for Kg Hujung Rintis and Mukim Kota Setia.

- Lack of communication between and among the stakeholders. Banners, posters, and e-flyers were distributed a month before the event.

- distance between the university and $\mathrm{Kg}$. Hujung Rintis. The driving time is six hours return.

- The villagers' cooperation and mindset.

The limitations are linked to the challenges for the project. The challenges were:

Firstly, commitment from both sides; the community and UCS. From the village, information dissemination was limited because of the internet inaccessibility, e-literacy, and limited promotion of the activity by the kampung committee leaders. This resulted in limited attendance at the events, particularly from the village youths.

Secondly, community engagement efforts have to be reciprocal. There were no problems from the university's side as the projects were formally approved. But on the community's side, lack of mutual support was the main impediment. It is recommended that state and district leaders support future initiatives by universities.

Thirdly, the distance from UCS to Kg. Hujung Rintis, Perak is a 3-hour drive, one-way. Although the distance should not be an issue, the well-being of the researchers, members, and students embarking on a 3-hour trip should be of concern. That is, there has to be an overnight stay for the parties involved. Having said so, it is suggested that homestays be made available to any visitors to $\mathrm{Kg}$. Hujung Rintis or nearby villages in terms of location distance. This is because the events were scheduled to start very early in the morning.

Community engagement for capacity development purposes is littered with challenges. Some of the recommendations include consistent information cascade between the village heads and the villagers. As most of the villagers are senior citizens with limited educational background, the village heads need to visit the homes of the village folks. Furthermore, the rural society for most parts in Malaysia is still committed to culture and tradition. Invitations for any events require the younger set to visit each home and verbally invite the villagers. The act of paying respect to the elders is deeply ingrained at $\mathrm{Kg}$. Hujung Rintis.

\subsection{Conclusion}

To conclude, the project objectives via the live laboratory event were achieved after the successfully held events. The impact on the communities at Mukim Kota Setia, specifically at $\mathrm{Kg}$. Hujung Rintis were significant. The dual events led to reciprocal community engagement activities for Universiti Teknologi MARA, Cawangan Selangor, through the fulfillment of the research co-production or participatory action research goals. The follow-up of the two events facilitated the implementation of entrepreneurship upgrades for the cottage, small-scale products originating from $\mathrm{Kg}$. Hujung Rintis, Perak. The spill-over effects from community engagement through capacity building efforts for this rural village were sustainable development, the activation of local capabilities, and networking across various local stakeholder groups, especially for the Koperasi Desa Kg. Hujung Rintis, Perak. Recommendations for sustainable growth include eco-tourism, education-tourism, and gastro-tourism. Suggestions for future research co-production activities include studies on the culture and tradition of the villagers that are still being practiced, for example, their musical inclinations and instruments. It is expected that the wellbeing and socio-economic growth of the community will be significant in the years to come.

\section{Acknowledgments}

The two events were supported by Universiti Teknologi MARA, Cawangan Selangor (UCS), Puncak Alam Campus funds. The studies conducted were from Dana UCS (DUCS). We are grateful for the continuous support of Mr. Jamsari Ahmad Abdullah, Chairman, Koperasi Desa Muara Hujung Rintis Kampung Gajah Berhad, Perak and, Mr. Mettirosman Ayob, the community leader (Penghulu) of Mukim Kota Setia, and Mr. Norhisyam bin Karno, the Chief Assistant District Officer (Development), Land and District Office, Perak Tengah. Malaysia.

\section{References}

Abu Bakar, N. A., \& Wall, G. (2018). Why Ecotourism Failed as an Alternative Livelihood in Marine Park: The importance of community's involvement in park management. Environment-Behaviour Proceedings Journal, 3(9), 77-86. doi:10.21834/e-bpj.v3i9.1540 
Ahmad, J. (2012). Can a university act as a corporate social responsibility (CSR) driver? An analysis. Social Responsibility Journal, 8(1), 77-+. doi:10.1108/17471111211196584

Banks, S., Hart, A., Pahl, K., \& Ward, P. (2019). Co-producing research: A community development approach. Bristol, UK: Policy Press.

Bodorkos, B., \& Pataki, G. (2009). Linking academic and local knowledge: community-based research and service learning for sustainable rural development in Hungary. Journal of Cleaner Production, 17(12), 1123-1131. doi:10.1016/j.jclepro.2009.02.023

Cruz-Garcia, G. S., Sachet, E., Vanegas, M., \& Piispanen, K. (2016). Are the major imperatives of food security missing in ecosystem services research? Ecosystem Services, 19, 19-31. doi:10.1016/j.ecoser.2016.04.001

Huyse, H., Molenaers, N., Phlix, G., Bossuyt, J., \& Fonteneau, B. (2012). Evaluating NGO-capacity development interventions: Enhancing frameworks, fitting the (Belgian) context. Evaluation, 18(1), 129-150. doi:10.1177/1356389011430372

Kline, C., McGehee, N., \& Delconte, J. (2019). Built Capital as a Catalyst for Community-Based Tourism. Journal of Travel Research, 58(6), 899-915. doi:10.1177/0047287518787935

Möller, B. (2020) From Exclusion to Inclusion: The Understanding, Capacity, and Will to Change Local Government Practices. Advances in 21st Century Human Settlements (pp. 331-350)

Community-based participatory research: A guide to ethical principles and practice (2012).

Nuamcharoen, S., \& Dhirathiti, N. S. (2018). A case study of the co-production approach to the implementation of education for sustainable development in Thailand. Policy Futures in Education, 16(3), 327-345. doi:10.1177/1478210317739487

Restrepo, M. J., Lelea, M. A., \& Kaufmann, B. A. (2018). Evaluating knowledge integration and co-production in a 2-year collaborative learning process with smallholder dairy farmer groups. Sustainability Science, 13(5), 1265-1286. doi:10.1007/s11625-018-0553-6

Rintis, D. M. H. (2019). About Desa Muara Hujung Rintis. Retrieved from https://www.facebook.com/hujungrintis/

Schneider, F., \& Buser, T. (2018). Promising degrees of stakeholder interaction in research for sustainable development. Sustainability Science, 13(1), $129-142$. doi:10.1007/s11625-017-0507-4

Zamfir, I. (2017). Understanding capacity-building/capacity development: A core concept of development policy. European Parliament Think Tank. Retrieved from http://www.europarl.europa.eu/thinktank/en/document.html?reference=EPRS_BRI(2017)599411 